\title{
The Pandemic of COVID-19 and its Impact on Turkey
}

\author{
(D) Funda Şimşek \\ University of Health Sciences Turkey, Prof. Dr. Cemil Taşçığlu City Hospital, Clinic of Infectious Diseases and Clinical Microbiology, i̇stanbul, Turkey
}

\section{Abstract}

The world and our country go through a pandemic period called Coronavirus Disease-2019 (COVID-19), which affects the health of billions of people both physically and psychologically, and their social life and economy. On December 31, 2019, the World Health Organization (WHO) reported cases of pneumonia of unknown etiology in Wuhan, China, Hubei province. Findings compatible with fever, dispnea and pneumonic infiltration in the lung were detected in the cases. On January 7, 2020, this was identified as a new coronavirus that has not previously been detected in humans. The name of the disease was accepted as COVID-19, the virus was named as Severe Acute Respiratory syndromecoronavirus (SARS-CoV)-2 due to its similarity to SARS-CoV-2. The WHO classified the COVID-19 epidemic as the "public health emergency on an International scale" on January 30 and defined it as a global epidemic (pandemic) on March 10 due to the spread and severity of the virus to other countries. Studies on COVID-19 started on 10th of January in our country and on January 22, the Scientific Advisory Board of the Ministry of Health of the Republic of Turkey held its first meeting and measures were taken. The first COVID-19 case occurred on March 11, after neighboring countries such as Europe and Iran. After this date, local measures have been taken across the country to gradually prevent and reduce the spread of the virus in the community. It is the responsibility of the whole community to pay attention to the measures taken. The most important rules in preventing infection are the use of masks, maintaining social distance and paying attention to all measures. Healthcare professionals worked intensely and devotedly during this period, fulfilling their duties and will still continue till this period ends.

Keywords: COVID-19, pandemic, Turkey

\section{INTRODUCTION}

\section{Coronavirus Disease-2019 (COVID-19) Pandemic}

Pandemic is the general name given to outbreaks that spread and affect a wide area in more than one country or continent in the world. According to the definition of the World Health Organization (WHO), three criteria are sought in general terms for a disease to be a pandemic: emergence of a new virus or a mutated agent, its easy transmission to humans, and its easy and continuous transmission from person to person (1). Pandemic is announced by WHO when certain criteria are met. The reason for this announcement is that the disease poses a threat to all countries, in other words, the emerging new virus spreads quickly from person to person (1).
The degree of impact of the pandemic on the society varies depending on the infectivity and virulence of the virus, the immune status of the individuals in the society, the life habits and socio-economic status of the individuals, the risk factors, the quality of health services in their country and the climate $(1,2)$. It is possible to reduce the spread of infection in the community and thus the number of people who will be infected in the early stages of the pandemic and the number of patients that will occur due to the pandemic.

Severe Acute Respiratory syndrome-coronavirus-2 (SARS-CoV-2) emerged as a previously unknown virus in 2003 as the first international health emergency of the 21st century, causing hundreds of people to die. In September 2012, Middle East Respiratory syndrome (MERS)-CoV-2, which was also a member 
of the CoV family, was not shown in humans or animals before, was first described in Saudi Arabia in humans (2,3).

On December 31, 2019, the WHO China Country Office reported patients with pneumonia of unknown etiology in Wuhan, China's Hubei province. It was stated that there was a cluster in Wuhan South China Seafood City Market employees in the south of Wuhan. Fever, shortness of breath and radiological findings compatible with pneumonic infiltration in the lung were detected in the patients. On January 7, 2020, the agent was identified as a new CoV that was not previously detected in humans. Later, the name of the disease was accepted as COVID-19, and the virus was named as SARS-CoV-2 due to its close similarity to SARS-CoV-2 $(1,2)$.

The first imported patient was a 61-year-old Chinese woman reported from Thailand on January 13, 2020. In the following days, the number of countries reporting patients gradually increased, and there was an increase in patients with COVID-19 and deaths due to this infection in Iran, South Korea and Italy. The WHO classified the COVID-19 outbreak as an "international public health emergency" on January 30, and defined it as a global outbreak (pandemic) on March 11 due to the spread and severity of the virus in countries other than China, where the pandemic started first. In the ongoing process, significant increases in the number of patients were observed in Europe, then in North and South America and all over the world. As of the beginning of June 2020, the pandemic continues and patients are reported from almost all countries in the world $(1,3)$.

The first patient with COVID-19 in our country was observed on March 11 after neighboring countries such as Europe and Iran (1). Tables 1 and 2 show the number of patients and deaths in the continents and the top 10 countries with the highest number of patients on 15 June 2020 (4).

\section{General Information About COVID-19}

CoV-2 are enveloped RNA viruses with rod-like extensions on their surface. Because of these protrusions, these viruses are named as CoV (crowned virus). These viruses can cause self-limiting mild infections, such as common cold in the population, and more severe infections such as MERS and SARS $(2,3)$.

There are several subtypes of CoVs (HCoV-229E, HCoV-OC43, HCoV-NL63 and HKU1-CoV) found in humans that can be easily transmitted from person to person. These subspecies circulating among humans are mostly viruses that cause colds. However,

\begin{tabular}{|l|l|l|l|}
\hline \multicolumn{2}{|l|}{ Table 1. Status of patients with COVID-19 by continents (Worldometer 15 June 2020) (4) } \\
\hline Continent & Total number of patients & $\begin{array}{l}\text { Number of new patients (in the last 24 } \\
\text { hours) }\end{array}$ & Total number of deaths \\
\hline World & $8,108,667$ & 124,600 & 438,596 \\
\hline Africa & 254,214 & 9,636 & 6,793 \\
\hline America & $3,970,574$ & 64,180 & 207,291 \\
\hline Europe & $2,220,090$ & 13,612 & 183,215 \\
\hline Asia & $1,654,119$ & 37,157 & 41,158 \\
\hline Australia & 8,946 & 15 & 102 \\
\hline Covid-19: Coronavirus Disease-2019 & & \\
\hline
\end{tabular}

\begin{tabular}{|l|l|l|l|}
\hline \multicolumn{5}{|l|}{ Table 2. Top 10 Countries in the world by total number of pases (Worldometer 15 June 2020) (4) } \\
\hline Countries & Total number of patients & Number of new patients & Total number of deaths \\
\hline USA & $2,182,950$ & 20,722 & 118,283 \\
\hline Brazil & 891,556 & 23,674 & 44,118 \\
\hline Russia & 537,210 & 8,246 & 7,091 \\
\hline India & 343,026 & 10,243 & 9,915 \\
\hline UK & 296,857 & 968 & 41,736 \\
\hline Spain & 291,189 & 181 & 27,136 \\
\hline Italy & 237,290 & 301 & 34,371 \\
\hline Peru & 232,992 & 3,256 & 6,860 \\
\hline Iran & 189,876 & 2,449 & 8,950 \\
\hline Germany & 188,044 & 373 & 8,885 \\
\hline USA: United States of America, UK: United Kingdom & & \\
\hline
\end{tabular}


there are many CoV subspecies detected in animals, and it is known that these viruses can cause severe illness in humans by transmitting from animals to humans. As a result of detailed studies, it has been revealed that SARS-CoV-2 is transmitted to humans from musk cats and MERS-CoV-2 from dromedary camels $(2,3)$.

The reservoir of SARS-CoV-2 is still under investigation. All available evidence for COVID-19 suggests that SARS-CoV-2 is a zoonotic source $(2,3)$.

The disease is mainly transmitted by droplets. In addition, the droplets emitted by sick individuals through coughing and sneezing are transmitted by touching the mouth, nose or eye mucosa after contact with other people's hands $(2,3)$.

Since viruses can be detected in respiratory tract secretions of asymptomatic people, these people can be contagious.

The entire population is sensitive to COVID-19. Healthcare professionals are the most risky occupational group in terms of encountering the agent. Men, people over the age of 50, people with comorbidities (hypertension, heart disease, diabetes, malignancy, chronic obstructive pulmonary disease, kidney disease, etc), seasonal agricultural workers and those living in care and rehabilitation centers, schools, barracks, detention houses and immigration camps are vulnerable groups in terms of COVID-19 (2,3).

Generally, the incubation period varies between 2-14 days. The contagious period of COVID-19 is not known exactly. Common symptoms of infection are respiratory symptoms, fever, cough, and dyspnoea. Symptoms such as headache, sore throat, runny nose, muscle and joint pain, extreme weakness, loss of sense of smell and taste, diarrhea can also be seen. Although patients can be asymptomatic, pneumonia, severe acute respiratory tract infection, kidney failure, and even death may develop in severe patients $(2,3)$.

Contagiousness begins 1-2 days before the onset of symptoms, and the viral load increases during the onset of symptoms, decreasing rapidly in the first seven days, but may extend beyond the second week.

Management of patients with possible or definite COVID-19 is carried out according to "Patient Follow up Algorithm" (2).

Diagnosis is based on the determination of specific sequences of virus RNA using the polymerase chain reaction test and sequence analysis method in the sample taken from the throat and nose.

Antibody response [immunoglobulin (Ig)M, IgA and IgG] generally develops after a certain period of time in those who have had COVID-19. Therefore, serological tests cannot be used for diagnosis in the early period of the disease. Although the first antibody response (IgM) starts after 6-7 days, antibody positivity develops 10 days after the onset of symptoms in most patients. Whether the detected antibodies provide immunity and how long it can be detected $(\mathrm{IgG})$ are not clear today. Rapid antibody tests that detect IgM/IgG are currently used (2).

While the fatality rate was between $11 \%$ in the SARS and $35-50 \%$ in MERS-CoV-2, the fatality rate was reported as 3.8\% according to the COVID-19 report of the Republic of China. This rate is 2.6\% $(2,3)$ in our country as of 02 May 2020.

COVID-19 does not have a definitive treatment yet. Anti-viral, anticytokine/anti-inflammatory drugs are used and coagulopathy management is performed. Vaccine studies are ongoing (1).

\section{Situation in Turkey}

Studies on COVID-19 in our country started on January 10, 2020, and the first meeting of the Scientific Advisory Board of the Ministry of Health was held on January 22. The Ministry of Health published the "2019-nCoV Disease Healthcare Professionals Guide" on January 24 (2).

Thermal cameras were placed at airports. Citizens of the Republic of Turkey in Wuhan was brought to Turkey on January 31. The proposal to close Chinese flights was put into effect on February $3(1,5,6)$.

The Iran border was closed on February 23, and the Iraq border was closed on February 29, flights to South Korea and Italy were stopped. On the same date, it was announced by the Ministry of Health that field hospitals would be opened on the borders of Iran and Iraq $(5,6)$.

On March 10, the first patient with COVID-19 was reported from our country $(2,3)$.

On March 15, citizens returning from Umrah were quarantined in state dormitories in Ankara and Konya $(5,6)$.

The pandemic caused in taking radical decisions that led to important impacts and results in social, economic, political, economic, administrative, legal, military, religious and cultural fields in Turkey (6).

Education was suspended in schools and universities on March 16 , sports competitions were decided to be played without spectators, and mass prayers were suspended in mosques $(5,6)$.

All restaurants, cafes, museums, classrooms, courses, shopping malls, hotels; barbers, hairdressers and beauty centers; cafes, sports halls, concert venues, night clubs, and wedding/ 
engagement halls were temporarily closed; all citizens were prohibited from picnics and barbecues in forests, parks and gardens $(5,6)$.

In order to reduce the rate of spread of the pandemic and to maintain social distance between people, curfews were initiated for those aged $\geq 65$ and those with chronic diseases. The restriction was later extended to include children and young people aged $<20$. A call was made not to travel outside the country and not to leave the house unless required (6).

All kinds of scientific, cultural, artistic and similar meetings and activities were postponed with the Presidential Circular published on 20 March $(5,6)$.

On the same date, all hospitals with level 3 adult intensive care units, including at least two of the infectious diseases and clinical microbiology, chest diseases and internal medicine specialists, were defined as "pandemic hospitals" by the Ministry of Health. In the next period, all hospital staff went through very difficult times. All hospitals made pandemic-related arrangements according to their own conditions $(5,6)$.

With the circular issued by the Presidency on March 22, rotation and remote work in public institutions and organizations were allowed (1).

On March 23, Favipravir began to be used in Turkey (2).

The Minister of Health announced that healthcare workers would be paid additional wages for three months (6).

As of April 3, the Ministry of Health Scientific Board was expanded and the "Community Pandemic Management Board", consisting of Public Health faculty members, held its first meeting.

Turkish Airlines stopped domestic flights on April 3 (6).

It was obligatory to wear masks in public areas such as markets and markets, and entry and exit to 30 metropolitan cities and Zonguldak were banned (6).

The Ministry of National Defense announced that all summons, dispatch and demobilization procedures in military barracks were delayed for a month.

The Council of Judges and Prosecutors announced that all hearings, negotiations and discoveries were suspended until 15 June, except for detained and urgent matters and cases of time out $(4,6)$.

Airlines, especially Turkish Airlines, announced that have terminated all international and domestic flights until next notice $(5,6)$.
The obligation to use masks in public areas such as markets and bazaars was put into effect.

Intercity travels were subject to the permission of the governor and the application of infrequent seating in public transportation was started.

Hundreds of settlements, villages and towns were quarantined under COVID-19 measures.

In order to minimize the economic effects of the pandemic, many regulations were made and support packages were announced.

Flexible working system with minimum personnel in private and public sector was introduced $(5,6)$.

In accordance with the law, the Ministry of Family, Labor and Social Services imposed a three-month dismissal ban on employers.

On April 9, the treatment of patients with COVID-19 was included in the scope of emergency.

On the same date, it was announced that a 1.000-room field hospital would be established on the Atatürk Airport grounds and in Sancaktepe $(5,6)$.

On 11-12 April 2020, a large-scale curfew was declared for the first time $(5,6)$.

It was announced that the curfew would continue in thirty metropolitan cities and Zonguldak between April 23-26.

On April 29, the Minister of Health announced that 7.428 healthcare workers were infected.

A curfew was declared between 1-3 May (2).

The "normalization calendar" was announced on May 4. According to this calendar, it was announced that the travel restrictions in 7 provinces would be lifted and hairdressers, barbers and shopping centers would be opened on May 11 .

It was announced by the President that the higher education institutions examination which was previously announced to be held at the end of July, would be held at the end of June by pulling forward one month $(5,6)$.

In a statement, the Ministry of Foreign Affairs announced that 473 Turkish citizens died from CoV abroad. In addition, more than 65 thousand Turkish citizens from 103 countries were brought to Turkey by evacuation $(5,6)$.

One hundred and sixteen countries requested help from Turkey. Medical aid materials including N95 masks, overalls, protective glasses, respirators, test kits and visors were sent to 44 countries, 
including the United States of America, the United Kingdom, Spain, Italy and Iran, which were most affected by the epidemic $(1,6)$.

Between 23-26 May 2020, curfews were imposed in all 81 provinces for four days, including Eve and Ramadan Feast.

In early June, after the decision to enter the normalization process and abolish the bans, it was observed that there was a relaxation and relief in the measures, despite giving continuous information on social distance and the use of masks in order not to increase the transmission. Due to the public's complacency in obeying the rules, a partial increase in the number of patients was observed in mid-June.

As of June 11, 2020 the total number of patients with COVID-19 was 174,023 and the number of patients who lost their lives due to COVID-19 was 4,763 in Turkey. Of the current patients, 643 patients are being treated in intensive care units, and 266 of them are receiving respiratory support. 147,860 patients recovered and were discharged (2).

Until June 11, 2020, 2,500,890 people were tested. While İstanbul was the city with the highest number of patients, it was followed by İzmir, Ankara, Kocaeli and Konya, respectively $(5,6)$.

\section{The Role of Media in Pandemic}

The media played a major role in the pandemic since the first patient was seen. In this process, the media was effective in informing the public and in managing the risk and motivating the public. The media opened the subject to discussion from different angles by presenting patient and death statistics and at the same time helped the audience/readers to be informed about the developments in the world (5).

In this process, it was seen that there was a large number of false information as well as correct information. Especially before encountering patients in Turkey, lots of news about ways to destroy the virus and to strengthen the immune system with non-evidence-based data, were given (4). In addition to expert scientists in this field, news, programs and broadcasts were made that included the opinions of physicians from different specialties making it difficult for the society to access correct and healthy information. Anxiety level increased in the society (5).

\section{CONCLUSION}

Turkey is among the countries affected by the outbreak relatively late. The pandemic has led to many important effects and consequences in social, economic, political, economic, administrative, legal, military, religious and cultural areas in
Turkey. It is obvious that the COVID-19 pandemic will affect our country and our health system for a long time. During the COVID-19 pandemic, the Scientific Committee Guidelines have been taken as a basis for patient management and have been updated periodically. In the guide, last updated on June 1, 2020, information and recommendations are available on management of pandemic, strategies and practices to be followed when encountering a patient with COVID-19 or contact, COVID-19 infection chain (source, transmission route, susceptible people), patient definitions and diagnostic methods. The guideline has been mainly prepared in line with WHO recommendations and is updated in line with current WHO recommendations and scientific developments. In this process, contact tracing teams have been established in provinces under the organization of Provincial Health Directorates. In some provinces, Community Health Center employees mainly work in this task, while in some provinces oral and dental health workers or different healthcare workers are involved in contact tracing.

Guidelines are guiding on issues such as Return to Normalization Plan in Hospitals, Infection Control Measures, and Pandemic Management in the Community in the COVID-19 pandemic and are renewed within the framework of changing conditions.

Since the COVID-19 pandemic has not been completely terminated, the risk continues until an effective treatment and/ or vaccine specific to the virus is found. During the pandemic period, the need for other health services has also increased. For this reason, taking into account that the pandemic continues, it is inevitable that other health services will start. This situation reveals the necessity of providing services within the same system for patients with and without COVID-19. Points to be considered here are ensuring the continuity of COVID-19-related precautions and healthcare services, keeping hospitals safe for patients with and without COVID-19, ensuring the safety of healthcare professionals, ensuring equal access and safety to all patients, and ensuring that personnel and healthcare services are to regulate gradually.

\section{Ethics}

Peer-review: Externally peer-reviewed.

Financial Disclosure: The authors declared that this study received no financial support.

\section{REFERENCES}

1. World Health Organization. Coronavirus Diseases. Available from: URL: https://covid19.who.int/ 
2. T.C Sağlık Bakanlığı. Covid-19 Rehberi, 1 Haziran 2020. Available from: URL: https://covid19.saglik.gov.tr/TR-66301/covid-19-rehberi.html

3. Türk Klinik Mikrobiyoloji ve İnfeksiyon Hastalıkları Derneği. Coronavirus hakkında bilgi notu. Available from: URL: https://www.klimik.org. $\operatorname{tr} / 2020 / 01 / 25 /$ saglik-calisanlari-icin-yeni-koronoavirus-hakkinda-bilginotu/
4. Worldometer 2020, www.worldometerinfo $>$ coronavirus

5. Tuba Bilimler Akademisi. Covid-19 Pandemi Değerlendirme Raporu. Available from: URL: http://www.tuba.gov.tr/tr/yayinlar/suresizyayinlar/raporlar/1.-versiyon-covid-19-pandemi-degerlendirme-raporu

6. TTB COVID-19 Pandemisi Değerlendirme Raporu.www.ttb.org.tr 